\title{
PERAN KOMUNIKASI EFEKTIF PEMIMPIN DALAM MENINGKATKAN KINERJA INSTITUSI
}

\author{
Binti Nasukah ${ }^{1}$, Sulistyorini ${ }^{2}$, Endah Winarti ${ }^{3}$ \\ ${ }^{1}$ Sekolah Tinggi Ilmu Tarbiyah Ibnu Sina, Malang, Jawa Timur, Indonesia \\ 2Institut Agama Islam Negeri Tulungagung, Jawa Timur, Indonesia \\ ${ }^{3}$ Institut Agama Islam Darullughah Wadda'wah, Pasuruan, Jawa Timur, Indonesia \\ Email : bnasukah@gmail.com ${ }^{1}$,sulistyorini12@yahoo.com²,endahwinarti002@gmail.com ${ }^{3}$
}

DOI: http://doi.org/10.33650/al-tanzim.v4i1.899

\begin{tabular}{l|l|l} 
Received: Januari 2020 & Accepted: Maret 2020 & Published: Maret 2020
\end{tabular}

\begin{abstract}
:
This study aims to identify and understand two important things, namely; characteristics of effective communication of school principals and the role of effective communication of school principals in improving institutional performance. This research uses a qualitative approach to the type of library research, by collecting data from; books, kitab, journals, articles. Data analysis was performed using content analysis. Through the literature study, the results show that: first, there are six characteristics of effective communication of leaders: being gentle, not being rude in speech, not being stubborn, forgiving and asking for forgiveness, inviting deliberation, and committed to conducting joint decisions and resignation to Allah SWT. Second, effective communication leaders play a role in; 1) Increase the effectiveness in sharing the vision of the Mission; 2) Improving the performance of the staff in the teacher's specialty; 3) Establishing partnerships with the school community 4) building a conducive school climate; and 5) Increasing the students' achievements. The results implicates on the importance of leaders of Islamic institutions to have the characteristics of effective communication, so it can play a role in improving the performance of the Institution.
\end{abstract}

Key words : Communication, leader, institution performance

\begin{abstract}
Abstrak :
Penelitian ini bertujuan untuk mengidentifikasi dan memahami dua hal penting, yaitu; karakteristik komunikasi efektif kepala sekolah dan peran komunikasi efektif kepala sekolah dalam meningkatkan kinerja institusi. Penelitian ini menggunakan pendekatan kualitatif jenis library research, dengan cara mengumpulkan data-data dari; buku, kitab, jurnal, artikel. Analisis datanya dilakukan dengan menggunakan content analysis. Melalui studi kepustakaan, didapatkan hasil bahwa; Pertama, terdapat enam karakteristik komunikasi efektif pemimpin, yaitu; sikap lemah lembut, tidak kasar dalam ucapan, tidak keras hati, memaafkan dan memohonkan ampun, mengajak bermusyawarah, serta berkomitmen menjalankan keputusan bersama dan bertawakkal. Kedua, komunikasi efektif pemimpin berperan dalam; 1) meningkatkan efektifvitas dalam berbagi (sharing) visi misi; 2) meningkatkan kinerja para staf khususnya guru; 3) membangun kemitraan dengan komunitas sekolah 4) membangun iklim sekolah yang kondusif; 5) meningkatkan capaian prestasi peserta didik. Hasil kajian berimplikasi pada pentingnya pemimpin lembaga pendidikan Islam untuk memiliki karakteristik komunikasi efektif, sehingga dapat berperan dalam meningkatkan kinerja insitusi.
\end{abstract}

Key words : Komunikasi, pemimpin, kinerja institusi 


\section{PENDAHULUAN}

Dalam pengelolaan lembaga pendidikan Islam, kepala sekolah seringkali dihadapkan pada pertanyaan, bagaimana seharusnya sebuah lembaga itu dikelola dan dipimpin untuk mencapai kinerja yang maksimal (Fathorrazi, 2017). Pertanyaan ini mengarahkan pada atensi untuk membahas dan meneliti, berbagai aktivitas dan aksi yang dapat mengarahkan pada pencapaian tersebut. Studi mendapati bahwa 60 \% capaian institusi ditentukan oleh kualitas dan kinerja kepala sekolah, di mana komunikasi efektif menjadi indikator profesionalitas seorang pemimpin sekolah yang excellent (Wentz, 1998); (Tyler, 2016).

Komunikasi yang dilakukan oleh kepala sekolah meliputi; struktur dan fungsi organisasi, hubungan antar manusia, komunikasi dan proses pengorganisasian serta budaya organisasi (Mulyadi, 2015), yang bertujuan untuk mempersatukan individu-individu yang tergabung didalamnya (Afkarina, 2018). Seiring dengan perkembangan ritme organisasi pada lembaga pendidikan, akhirnya menuntut berkembangnya gaya-gaya komunikasi pemimpin dalam upaya mencapai komunikasi yang efektif (Naway, 2017).

Dalam konteks lembaga pendidikan Islam, kepala sekolah menghadapi tanggung jawab yang semakin berat, baik untuk dapat menciptakan komunikasi efektif dalam perannya sebagai pemimpin dalam komunitas yang melibatkan banyak stakeholder. Mendels (2012) mengingatkan bahwa tugas kepala sekolah saat ini perlu berfokus pada dua capaian kinerja optimal, yaitu dalam manajerial dan pembelajaran-peningkatan capaian prestasi belajar siswa. Melalui komunikasi efektif, maka fungsi manajerial yang dilakukan dalam pengelolaan insitusi diawali dari fungsi perencanaan, implementasi dan pengawasan dapat dicapai (Syam, 2017). Tidak hanya proses-proses manajerial, komunikasi juga menjadi bagian penting dalam mengkoordinasikan upayaupaya peningkatan efektivitas dan visibilitas insitusi (Iacob, 2015).

Studi dari McEwan (2003) juga mengidentifikasi peran komunikator sebagai elemen yang paling penting bagi kepala sekolah yang efektif. Menurut Tobin (2014), mereka menghabiskan lebih dari 70-80\% dari waktu dalam kegiatan komunikasi interpersonal, yang sebagian besar di antaranya adalah tatap muka dan melalui telepon. Belum lagi jenis-jenis komunikasi lain seperti surat-surat elektronik (email), media sosial, dsb, menjadikan wewenang kegiatan komunikasinya semakin kompleks (Lunenburg, 2010). Kompleksitas kegiatan ini hanya akan menjadi kegiatan yang membuang tenaga dan waktu, jika tidak diarahkan pada penciptaan komunikasi efektif yang diarahkan pada tujuan peningkatan kinerja organisasi.

Pentingnya komunikasi efektif kepala sekolah dalam meningkatkan kinerja telah menginspirasi berbagai penelitian yang mengungkap peran komunikasi efektif, dalam meningkatkan kinerja sekolah. Meski demikian, masing-masing hanya berfokus pada satu faktor secara parsial, seperti: menciptakan pemahaman bersama tentang visi dan misi (Battilana, 2010); membangun kepercayaan antara kepala sekolah dan guru (Tyler, 2016); membangun kemitraan dengan pihak-pihak eksternal sekolah (Myende, 2013); menciptakan suasana belajar yang kondusif (Hill-Berry, 2019) dan 
meningkatkan capaian prestasi siswa (Dohlen, 2018). Dibutuhkan sebuah studi yang dapat menggambarkan secara komprehensif peran komunikasi efektif dalam meningkatkan kinerja institusi yang mengarahkan pada kinerja aktual peningkatan capaian prestasi peserta didik.

Di sisi lain, peneliti juga berusaha mengungkap karakteristik komunikasi efektif kepala sekolah seperti: peduli, memahami, berpengetahuan, mendengarkan, disiplin, perilaku baik, menghargai, membantu, memotivasi, sabar, fleksibel, jujur, bertanggung jawab, ramah, dsb (Schulte dkk., 2010). Meski demikian, Islam pada dasarnya memiliki sosok suri tauladan Rasulullah Muhammad SAW yang memiliki karakteristik komunikasi efektif karena keberhasilannya dalam dakwah mengajarkan Islam (Dahlan, 2014). Karakteristik ini patut untuk diungkap sebagai role model bagi para pemimpin lembaga pendidikan Islam, agar mereka juga dapat mengambil hikmah dalam upaya pengelolaan lembaga pendidikan Islam dapat berkinerja lebih baik.

Berdasarkan latar belakang tersebut, penelitian ini berupaya mengkaji dua hal pokok, yaitu; karakteristik komunikasi efektif kepala sekolah dan peran komunikasi efektif kepala sekolah dalam meningkatkan kinerja institusi yang didasarkan pada karakteristik kepemimpinan efektif Rasulullah SAW dan hasil dari penelitian para ahli manajemen pendidikan.

\section{METODE PENELITIAN}

Penelitian ini menggunakan pendekatan kualitatif, dengan jenis library research (studi kepustakaan), yaitu jenis penelitian yang dilakukan dengan cara mengumpulkan data-data dari; buku, kitab, jurnal, artikel, dan tulisan-tulisan tertentu. Library research berkenaan dengan metode pengumpulan data pustaka dengan membaca, mencatat dan mengolah dokumen bahan-bahan penelitian. Teknik pengumpulan data menggunakan dokumentasi, dengan mencari data mengenai hal-hal yang dibahas, dari dokumen yang berupa transkrip, buku, majalah, laporan penelitian, dst (Trianto, 2014).

Data yang dikumpulkan adalah data-data literer atau bahan-bahan pustaka yang koheren dan sesuai dengan obyek pembahasan. Data dianalisis menggunakan analisis isi (content analysis), yaitu menganalisis muatan teks, yang berupa kata-kata, gambar, simbol, gagasan, tema dan berbagai bentuk pesan yang dikomunikasikan dalam dokumen tersebut. Tujuan analisis isi adalah memahami data untuk mengungkap makna yang terkandung di dalamnya dan berusaha mendapatkan pemahaman terhadap pesan yang dipresentasikan.

\section{HASIL DAN PEMBAHASAN}

\section{Karakteristik Komunikasi Efektif Kepala Sekolah}

Komunikasi efektif, menjadi bagian penting organisasi dalam upaya pencapaian tujuan. Seringkali organisasi mengalami kegagalan dalam mencapai tujuan disebabkan oleh faktor komunikasi yang tidak efektif. Misalnya, perintah dari seorang pemimpin yang pada hakikatnya adalah bagian dari kegiatan komunikasi, seringkali menjadi tidak jelas dan sulit diimplementasikan karena komunikasi yang dijalankan tidak efektif (Tisnawati \& Saefullah, 2005). 
Diantara masalah yang muncul dalam kegiatan komunikasi dikenal dengan istilah miscommunication (kekeliruan dalam komunikasi), sehingga proses komunikasi tidak berjalan sebagaimana yang diinginkan. Adanya problem kekeliruan dalam komunikasi seringkali menyebabkan munculnya komunikasi yang sulit dipahami untuk kemudian diimplementasikan dalam program organisasi (Yusuf, 2018). Problem lainnya adalah komunikasi yang searah (top-down), yang cenderung kaku, sehingga dapat menyebabkan organisasi kurang dinamis dalam menghadapi berbagai persoalan yang terkadang perlu diatasi segera.

Berbagai kendala yang dihadapi dalam organisasi, membutuhkan upaya bagaimana agar komunikasi dalam organisasi sebagai sebuah hubungan timbal-balik, tidak hanya memainkan peran dalam pengiriman pesan kepada pihak lain, tetapi juga dapat menjadi perekat yang bersifat sosio-psikologis, terlebih dalam sebuah organisasi yang menghendaki kerjasama yang sinergis. Dalam hal ini diperlukan karakter komunikasi efektif dari pemimpin lembaga pendidikan Islam.

Rasulullah SAW sebagai sosok mulia, merupakan suri tauladan bagi umat Islam. Tugas beliau sebagai Rasul dan mendakwahkan Islam mencapai keberhasilan luar biasa, di mana dapat meng-Islam-kan penduduk Mekah dan Madinah. Hal ini tidak terlepas dari keefektifan komunikasi beliau kepada umat yang didakwahinya.

Setidaknya ada enam karakteristik komunikasi efektif yang dapat ditunjukkan oleh kepala sekolah dengan mendasarkan pada konsep kepemimpinan efektif Rasulullah, yaitu; Perilaku lembut, tidak kasar dalam ucapan, tidak keras hati, memaafkan, musyawarah dan memiliki komitmen.

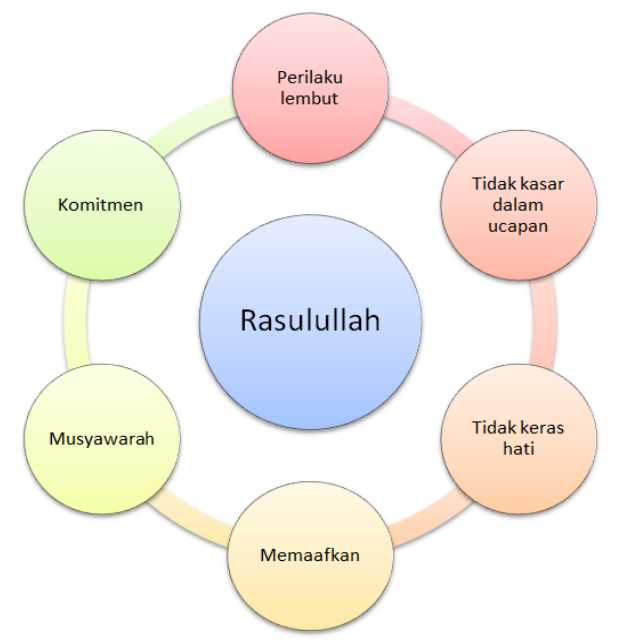

Gambar 1 : Integrasi kepemimpinan Rasulullah dalam komunikasi organisasi

Gambar 1 tersebut menunjukkan sifat terpuji Rasulullah dalam kegiatan komunikasi pada organisasi yang beliau pimpin. Perilaku lembut menjadi kunci komunikasi efektif pemimpin pada lembaga pendidikan Islam yang pertama. Hal ini telah terbukti sebagaimana yang diteladankan Rasulullah SAW, bahwa karakter inilah yang menyebabkan dakwah beliau berhasil. Tidak hanya kepada para sahabat, tetapi juga dalam menghadapi orang-orang yang justru memusuhi dan menentang beliau. Dengan kelemahlembutan, mereka yang 
pada awalnya memusuhi kemudian tersentuh dengan perilaku lembut Rasulullah SAW dan menjadi pengikut setia beliau. Akhlak mulia Rasulullah SAW telah menjadi sarana dakwah yang ampuh, yang dapat menarik manusia ke dalam agama Allah (Mubasyaroh, 2017).

Dalam konteks lembaga pendidikan Islam, Kelemahlembutan seorang pemimpin atau kepala sekolah, akan menjadikan pemimpin mendukung keberadaan atasan dengan sepenuh hati (Taufiq, 2004). Lemah lembut mendorong hubungan antara pemimpin dengan yang dipimpin dipenuhi suasana saling memahami, saling percaya, saling terbuka, sehingga memunculkan motivasi kreativitas dan inisiatif yang jauh dari suasana tertekan dan penuh kekhawatiran (Djalaluddin, 2014). Dengan demikian seluruh anggota organisasi yang berada di sekolah akan merasa diayomi dan terjalin komunikasi yang baik antar semua anggota organisasi, baik top-down; down-top maupun horisontal.

Kunci komunikasi efektif pemimpin yang kedua adalah tidak kasar dalam ucapan. Menurut Kojin (2017) lafadz 'Fadhdhan', memiliki makna kasar dalam bergaul, baik dalam ucapan atau perbuatan. Seorang pemimpin harus menghindari berkata-kata kasar yang dapat menyakiti hati. Perkataan kasar akan menyebabkan komunikasi yang terjalin tidak dapat berjalan dua arah, disebabkan adanya tekanan rasa takut dan khawatir berlebih pada bawahan.

Terdapat delapan jenis perkataan (Qoulan) yang tersebut dalam alQur'an, yang dapat diterapkan pemimpin lembaga pendidikan Islam: ma'rufan, kariman, maysuran, balighan, layyinan, sadidan, tsaqilan, dan ahsan (Hefni, 2017). Qaulan ma'rufan mengajarkan pemimpin agar memiliki ungkapan-ungkapan baik (tidak kotor), yang ramah, tidak menyinggung perasaan, dan tidak berpotensi memunculkan niat jahat bagi yang mendengarkannya. Qaulan kariman mengajarkan agar memiliki perkataan yang memiliki nilai (tidak murahan), sehingga yang diajak bicara merasa dihargai dan dihormati. Qaulan maysuran mengajarkan agar pemimpin memiliki perkataan yang menyenangkan dan memberi harapan kepada yang mendengarkan untuk mendapatkan kebaikan darinya. Qaulan layyinan mengajarkan untuk berkomunikasi kepada bawahan dengan perkataan lemah lembut dan tidak memvonis. Qaulan sadidan mengajarkan agar menyampaikan perkataan benar dan tepat sasaran. Qaulan tsaqilan mengajarkan agar pemimpin memiliki perkataan yang berbobot, penuh makna. Dan ahsanu qaulan mengajarkan agar pemimpin senantiasa mengucapkan kata-kata terbaik.

Komunikasi efektif selanjutnya, mensyaratkan karakter ketiga, yaitu pemimpin yang tidak keras hati. Keras hati seorang pemimpin dapat menyebabkan hilangnya kreativitas bawahan (Djalaluddin, 2014). Pemimpin yang keras hati dapat menyebabkan setiap individu yang ada di sekolah memiliki keraguan dan ketakutan ketika akan menyampaikan sesuatu. Komunikasi yang terjalin bisa mengarah pada bentuk-bentuk pujian berlebihan kepada pemimpin yang hanya ingin menyenangkan hati pemimpin (Widyastuti, 2017). Dengan demikian segala permasalahan yang ada akan diselesaikan dalam suasana penuh ketakutan. Jenis komunikasi yang terjalin hanyalah top-down. 
Karakter keempat dari komunikasi efektif pemimpin adalah memaafkan dan memohonkan ampun. Pemimpin lembaga pendidikan Islam harus memahami bahwa setiap orang dapat melakukan kesalahan, sehingga dapat memaafkan kesalahan mereka, serta mendoakan ampunan untuk mereka. Menurut Taufiq (Taufiq, 2004), dengan sifat kasih sayang dan pemaaf akan timbul rasa sayang dan loyalitas dari bawahan. Kekerasan pemimpin tidaklah akan menumbuhkan kewibawaan, tetapi justru menimbulkan kemunafikan dan penghianatan. Komunikasi yang terjalin antara pemimpin dan bawahan tidak akan sehat.

Karakter kunci komunikasi efektif pemimpin kelima adalah musyawarah. Musyawarah artinya mengajak duduk bersama dalam menyelesaikan setiap perselisihan dan persoalan. Musyawarah menjadi sarana komunikasi efektif karena di dalamnya orang dapat menyampaikan pendapat secara terbuka, terdapat keharusan sikap menghargai pendapat orang lain. Hal ini menyebabkan terjalinnya komunikasi baik antar sesama anggota di lembaga pendidikan Islam.

Pratiwi \& Sunarso (2018) menjelaskan manfaat dari musyawarah antara lain; 1) Dapat menyatukan visi dan misi; 2) Menerangi akal-pikiran; 3) Menutupi kekurangan yang ada pada orang lain; 4) Membuahkan keputusan yang bijak, tepat dan benar. Dengan musyawarah, keputusan yang diambil dapat disepakati bersama, sehingga terjalin kekompakan dalam pengelolaan lembaga pendidikan Islam.

Keenam, pemimpin memiliki komitmen-azimah (tekad kuat), dan dilanjutkan dengan tawakkal. Pemimpin harus memiliki komitmen kuat dalam menjalankan keputusan yang diambil dalam musyawarah. Segala hal yang telah diputuskan harus dilaksanakan dengan komitmen kuat meski kadang tidak sesuai dengan kehendak pribadi pemimpin, tetapi telah menjadi keputusan mayoritas. Komitmen tersebut diikuti dengan usaha maksimal yang diakhiri dengan tawakkal kepada Allah SWT. Tawakkal merupakan salah satu sifat imaniyah, di mana keberhasilan atas segala upaya yang dilaksanakan diserahkan hasilnya sepenuh hati kepada Allah SWT (Djalaluddin, 2014). Kepasrahan kepada Allah SWT akan menjadikan pemimpin memiliki kesadaran penuh bahwa segala sesuatu terjadi karena ada yang berkehendak. Dengan demikian, pemimpin pada suatu lembaga pendidikan Islam akan terjauhkan dari karakter sombong dan semena-mena.

Dengan keenam karakter tersebut, seorang pemimpin dapat menjalin komunikasi dengan anggota lembaga secara efektif. Di antara jenis komunikasi yang paling sulit pelaksanaannya dalam pengelolaan lembaga pendidikan adalah komunikasi down-top-komunikasi dari staf kepada pimpinan. Seringkali, pemimpin memiliki karakter-karakter yang membuat bawahan takut, khawatir dan tidak bisa terbuka dalam mengkomunikasikan masalah. Pemimpin dengan karakter lembut, tidak kasar dalam ucapan, memaafkan serta menyukai musyawarah, akan menjadikan para staf merasa dihargai, dan menjadikan komunikasi dapat berjalan baik, sehingga tujuan pelaksanaan pendidikan juga dapat tercapai dengan baik. 


\section{Peran Komunikasi Efektif Pemimpin dalam Meningkatkan Kinerja Institusi}

Berbagai studi menunjukkan peran penting komunikasi efektif pemimpin dalam upaya meningkatkan kinerja lembaga pendidikan Islam, yang hasil akhirnya adalah peningkatan kinerja capaian belajar peserta didik. Hasil kajian berbagai sumber mengindentifikasi peran tersebut antara lain; 1) meningkatkan efektifvitas dalam membagi (sharing) visi misi; 2) meningkatkan kinerja para staf, khusunya guru; 3) membangun kemitraan dengan komunitas sekolah; 4) membangun iklim sekolah yang kondusif; 5) meningkatkan capaian prestasi peserta didik. Peran ini dapat digambarkan sebagai berikut;

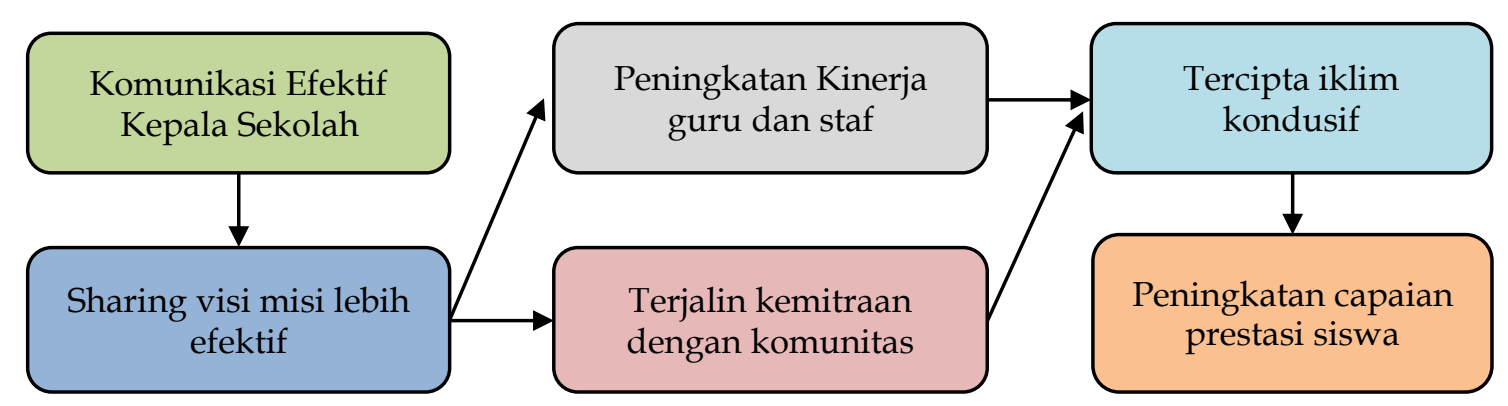

Gambar 2 : Peran komunikasi efektif kepala sekolah dalam meningkatkan kinerja institusi

Gambar 2 tersebut, dapat dijelaskan sebagai berikut;

Pertama, komunikasi efektif kepala sekolah sangat berperan dalam meningkatkan efektivitas dalam membagi visi misi untuk pencapaian tujuan bersama. Hasil studi Battilana et al., (2010) mendapati bahwa; untuk mengarahkan organisasi menuju kesuksesan, para pemimpin menggunakan berbagai bentuk komunikasi untuk menciptakan pemahaman bersama tentang visi dan misi suatu organisasi. lebih jauh lagi, visi dan misi tersebut tidak hanya sekedar berbagi, tetapi melalui komunikasi yang efektif, maka komitmen tim dapat dibangun dalam upaya pencapaian visi misi tersebut.

Pemimpin atau kepala sekolah perlu memahami bahwa; organisasi merupakan wadah, badan, atau tempat berkumpulnya dua orang atau lebih untuk bekerja sama dalam mencapai tujuan tertentu (Amirullah, 2015). Artinya, terdapat sekelompok orang yang saling berinteraksi untuk merealisasikan tujuan bersama (Siswanto, 2005), yang dicapai secara efektif dan efisien. Efektif berarti membuat keputusan dengan tepat dan mengimplementasikannya dengan sukses, sedangkan efisien berarti menggunakan berbagai sumber daya secara bijaksana dan dengan cara yang hemat biaya (Usman, 2011).

Pemahaman tentang makna organisasi tersebut mengajarkan kepada pemimpin bahwa insititusi dapat lahir dan berkembang karena; 1) ada interaksi yang berarti komunikasi antara satu dengan yang lain; 2) ada kerjasama, dalam artian ada kerelaan untuk melakukan tindakan (pengabdian); 3) ada tujuan bersama yang ingin dicapai; dan 4) ada cara pencapaian secara efektif dan efisien. Pemahaman ini mengarahkan pada salah satu unsur terpentingnya adalah interaksi atau komunikasi yang efektif, di mana melalui komunikasi efektif, pemimpin dapat membangun tumbuhnya kesepakatan untuk saling 
mengabdi atau menyumbang tindakan untuk mencapai tujuan bersama.

Menurut Fattah (2016), organisasi merupakan sebuah proses dinamis melalui kegiatan pengorganisasian, di mana kegiatan diatur dan dialokasikan di antara para anggota, sehingga tujuan organisasi itu dapat tercapai secara efektif. Dari perspektif proses pengaturan dan pengalokasian ini, peran komunikasi efektif menjadi sangat penting. Komunikasi efektif dalam proses organizing, berperan dalam share meaning, agar semua orang dapat memiliki mimpi yang sama, sebagaimana tujuan yang ditetapkan.

Kedua, komunikasi efektif kepala sekolah dapat meningkatkan kinerja para staf khusunya guru. Sudah sejak lama penelitian mengungkap keterkaitan antara kepuasan guru pada kebijakan sekolah dan hubungan guru dengan kepala sekolah (Hidayat \& Patras, 2018). Capaian siswa dapat ditingkatkan ketika guru dan pimpinan dapat saling bekerja sama. Dalam hal ini terjalin komunikasi yang baik dan berbagai nilai-nilai bersama. Keberhasilan kepala sekolah dalam mengkomunikasikan visi misi dan nilai-bilai bersama kepada guru dan staf melalui berbagai bentuk perilaku komunikasi, dapat mendorong guru untuk semakin berkinerja baik.

Hasil penelitian dari Tyler (2016) tentang perilaku kepemimpinan kepala sekolah menyimpulkan bahwa; keterampilan komunikasi efektif diperlukan untuk membangun kepercayaan antara kepala sekolah dan guru, untuk mengarahkan guru ke arah pengajaran yang efektif. Komunikasi kepala sekolah kepada guru diterapkan dalam upaya memotivasi guru untuk semakin meningkat kinerja. Bentuk-bentuk perilaku komunikasi tersebut dengan cara sering bertatap muka dan komunikasi pribadi, melakukan pertemuan rutin seluruh sekolah, dan pendampingan untuk mengetahui berbagai problematika yang dihadapi guru, dalam peningkatan kinerjanya.

Pendidik yang merupakan faktor sentral dalam kegiatan pembelajaran. Meski demikian, mereka kerap tidak berhasil menciptakan suasana pembelajaran yang efektif. Dalam hal ini, kemampuan pendidik dalam berkomunikasi dengan peserta didik menjadi sangat urgen (Aziz, 2017). Diperlukan pemahaman pendidik pada metode, strategi, dan hambatan komunikasi dalam pendidikan, sehingga komunikasi dalam proses pembelajaran bisa berlangsung secara efektif (Wisman, 2017).

Oleh karena itu, kepala sekolah harus senantiasa memberikan arahan, motivasi dan peningkatan skill guru secara efektif, khusunya ketrampilan komunikasi. Hasil penelitian membuktikan bahwa; guru dengan kemampuan komunikasi yang baik, akan menciptakan kesuksesan dalam kegiatan belajar mengajar, dan berpotensi untuk menciptakan strategi-strategi komunikasi yang efektif (Ali \& Demiray, 2019). Dengan kemampuan komunikasi, guru dapat menciptakan suasana menyenangkan dalam pembelajaran, dan tujuan peningkatan prestasi siswa dapat terwujud.

Ketiga, komunikasi efektif kepala sekolah dapat mendorong terciptanya kemitraan dengan komunitas sekolah. Studi dari Ali \& Demiray (2019) secara gamblang menjelaskan bagaimana komunikasi efektif dapat berperan dalam membangun dan mempertahankan kemitraan dengan pihak-pihak eksternal sekolah. Menurut Swick (2003), komunikasi efektif adalah komunikasi yang 
dapat membangun kemitraan kerja yang kuat antara pemangku kepentingan internal sekolah (guru, manajemen, peserta didik, dan staf) dan pemangku kepentingan eksternal (orang tua, organisasi masyarakat, bisnis, institusi pendidikan tinggi, anggota komunitas lainnya) (Mahfuzhah, 2018). Dia lebih lanjut menyatakan bahwa; komunikasi efektif yang melibatkan semua pemangku kepentingan akan berdampak pada kinerja aktual dalam memperkuat pertumbuhan dan perkembangan peserta didik.

Komunikasi yang efektif membutuhkan jenis komunikasi dua arah dan mencerminkan kemitraan yang setara antara sumber yang berbeda, dalam hal ini, sekolah dan para pemangku kepentingan eksternal lainnya yang bermitra dengan mereka (Hughes \& Greenhough, 2006). Untuk itu, dibutuhkan strategi dalam upaya mendorong terciptanya komunikasi yang efektif dengan pemangku kepentingan eksternal, yang ditujukan untuk memfasilitasi keterlibatan aktif berbagai pemangku kepentingan tersebut. Miller (2007) menunjukkan bahwa; kemitraan membutuhkan komunikasi terbuka untuk membawa kepaduan pemikiran yang mengarahkan pemanfaatan komunitas dalam upaya pencapaian tujuan organisasi. Menurut Mncube \& Harber (2010), pemberdayaan komunitas dimaksudkan agar semua pihak saling terhubung dan tidak saling terpecah belah. Lebih lanjut dikatakan oleh Swick (2003), bahwa komunikasi dapat memperkuat mengatasi hal-hal yang berkaitan dengan perbedaan budaya, sehingga tidak merusak hubungan meski terdapat perbedaan. Dengan komunikasi efektif, hubungan kemitraan dapat terjalin dalam upaya mencapai tujuan bersama komunitas sekolah.

Keempat, komunikasi efektif kepala sekolah dapat menciptakan iklim belajar yang kondusif. Hasil studi Ali \& Demiray (2019) menemukan pentingnya komunikasi efektif pemimpin, sebagai faktor kunci sukses dalam menciptakan suasana belajar di mana peserta didik dapat belajar, meningkatkan kemampuan, tumbuh dan mencapai cita-cita mereka. Iklim kondusif ini dapat tercipta manakala seluruh komunitas pada organisasi memiliki kepuasan tinggi (Rahsel, 2017). Kepuasan ini tercipta karena kepala sekolah membangun hubungan baik dengan seluruh komunitas, baik internal dan eksternal.

Kepala sekolah harus dapat mengorganisasikan staf dan guru, dengan memperhatikan keterlibatan mereka dalam perencanaan maupun pembuatan keputusan. Tidak boleh ada keputusan yang dibuat tanpa pelibatan guru atau staf. Menurut Kilicoglu (2018), seorang pemimpin hendaknya dapat meningkatkan kemampuan mereka dalam mendistribusikan dan mengkoordinasikan berbagai tugas secara kolaboratif. Kemampuan mengatasi konflik, berkomunikasi face-to-face, dan juga memiliki sisi emosional yang memperhatikan problematika para guru dan staf, dibutuhkan pemimpin dalam mengelola sumber daya manusia yang beragam.

Untuk menciptakan iklim yang kondusif kepala sekolah dapat memulainya melalui perilaku yang konsisten dengan visi misi sekolah, serta mengembangkan tujuan yang jelas dalam upaya peningkatan capaian prestasi siswa. Menurut Cansoy (2018), kepala sekolah harus dapat mengidentifikasi dan mengimplementasikan strategi-strategi tepat dalam pencapaian visi misi 
sekolah. Dengan konsistensi tersebut, kepala sekolah dapat ikut membangun komitmen bersama, terjalin hubungan baik dengan komunitas internal dan eksternal, kinerja staf khususnya guru dapat ikut meningkat, sehingga terjalin iklim yang menjadikan peserta didik memiliki kepercayaan kepada sekolah (Siswatiningsih, 2019). Hasil akhirnya adalah peningkatan capaian prestasi peserta didik.

Kelima, pada akhirnya komunikasi efektif kepala sekolah dapat berperan dalam meningkatkan capaian prestasi peserta didik. Lembaga pendidikan adalah sebuah organisasi jasa dengan sistem yang memproses peserta didik menjadi lulusan dengan capaian kompetensi yang ditetapkan. Melalui komunikasi efektif, proses tersebut dapat berjalan baik, sehingga tujuan akhir dapat tercapai. Hasil studi Isik (2020) mengungkap bagaimana komunikasi dan interaksi pemimpin dapat berpengaruh terhadap capaian prestasi siswa. Peningkatan prestasi siswa dapat terwujud ketika terjalin komunikasi yang baik antara manajemen dengan guru (Goksoy, 2016). Kepala sekolah dapat menciptakan konsensus bersama antara staf dan guru dalam bentuk peraturan dan pemberdayaan. Konsensus juga diciptakan dengan stakeholder eksternal, sehingga seluruh komunitas yang terlibat dalam sekolah memiliki satu tujuan bersama. Iklim kondusif pun dapat tercipta dan terjaga. Pada akhirnya iklim kondusif dapat memberikan suasana pembelajaran menyenangkan, berujung pada meningkatnya capaian prestasi peserta didik.

\section{KESIMPULAN}

Sebagai sebuah sistem (kesatuan) sosial, lembaga pendidikan Islam memiliki sejumlah elemen yang saling berinteraksi dalam upaya pencapaian tujuan pendidikan. Untuk pencapaian tujuan secara efektif, interaksi dengan elemen-elemen dalam lingkungan tersebut harus disertai dengan komunikasi efektif pemimpin. Komunikasi efektif telah menjadi indikator dari profesionalitas seorang pemimpin sekolah yang excellent dalam meningkatkan produktivitas kerja tenaga pendidik dan kependidikan di sekolah.

Hasil kajian membawa implikasi agar para manajer lembaga pendidikan Islam dapat menerapkan berbagai berbagai karakteristik komunikasi efektif pemimpin yang diteladankan Rasulullah SAW. Dengan demikian, peran-peran yang teridentifikasi dalam upaya peningkatan kinerja institusi, menuju hasil akhir peningkatan capaian prestasi peserta didik, dapat dijalankan secara optimal.

\section{DAFTAR PUSTAKA}

Afkarina, N. I. (2018). Strategi Komunikasi Humas dalam Membentuk Public Opinion Lembaga Pendidikan. Jurnal Idaarah: Jurnal Manajemen Pendidikan, 2(1), 50-63.

Ali, O., \& Demiray, G. (2019). Study of the Relationship Between School Managers' Communicative Skills and Schools' Atmosphere. Journal of Education and Learning, 8(2), 145-164. 
Amirullah, H. B. (2015). Pengantar Manajemen. Yogyakarta: Graha Ilmu.

Aziz, A. (2017). Komunikasi Pendidik dan Peserta Didik dalam Pendidikan Islam. MEDIAKITA, 1(2), 173-184.

Yusuf, B. (2018). Manajemen Komunikasi dalam Pengelolaan Informasi Pembangunan Daerah. Jurnal Komunikasi Hasil Pemikiran Dan Penelitian, 4(1), 50-64.

Battilana, J., Gilmartin, M., Sengul, M., Pache, A.-C., \& Alexander, J. A. (2010). Leadership Competencies for Implementing Planned Organizational Change. The Leadership Quarterly, 21(3), 422-438.

Cansoy, R. (2018). The Relationship between School Principals' Leadership Behaviours and Teachers' Job Satisfaction: A Systematic Review. International Education Studies, 12(1), 37-52.

Dahlan, M. S. (2014). Etika Komunikasi dalam Al-Qur'an dan Hadits. Jurnal Dakwah Tabligh, 15(1), 115-123.

Djalaluddin, A. (2014). Manajemen Qur'ani: Menerjemahkan Idarah Ilahiyah dalam Kehidupan. Malang: UIN-Maliki Press.

Dohlen, V. H., \& Karvonen, M. (2018). Teachers' Self-Reported Leadership Behaviors in Formal and Informal Situations. International Journal of Teacher Leadership, 9(2), 69-89.

Fattah, N. (2016). Landasan Manajemen Pendidikan. PT. Remaja Rosdakarya.

Fathorrazi, A. (2017). Kepemimpinan Kepala Sekolah dalam Implementasi dan Pengembangan Kurikulum 2013. Al-Tanzim: Jurnal Manajemen Pendidikan Islam, 1(1), 56-63.

Goksoy, S. (2016). Analysis of The Relationship between Shared Leadership and Distributed Leadership. Eurasian Journal of Educational Research, (65), 295312.

Hefni, H. (2017). Komunikasi Islam. Jakarta: Prenamedia Group.

Hidayat, R., \& Patras, Y. E. (2018). Kepuasan Kerja Guru dan Peran Kepemimpinan Pendidikan: Survei Guru di Bogor dan Sekitarnya. Jurnal Manajemen Pendidikan (JMP), 7(3), 248-264.

Hill-Berry, N. P. (2019). Expanding Leadership Capacity toward Social Justice. Research in Educational Administration and Leadership, 4(3), 720-742.

Hughes, M., \& Greenhough, P. (2006). Boxes, Bags and Videotape: Enhancing Home-School Communication through Knowledge Exchange Activities. Educational Review, 58(4), 471-487.

Iacob, S. (2015). The Communication Paradigms in Education. Theoretical $\mathcal{E}$ Applied Economics, 22(4), 217-228.

Isik, A. N. (2020). Ethical Leadership and School Effectiveness: The Mediating Roles of Affective Commitment and Job Satisfaction. International Journal of Educational Leadership and Management, 8(1), 60-87.

Kilicoglu, Derya. (2018). Understanding Democratic and Distributed Leadership: How Democratic Leadership of School Principals Related to Distributed Leadership in Schools? Educational Policy Analysis and Strategic Research, 13(3), 6-23.

Kojin. (2017). Kosa Kata dalam Al-Qur'an. Malang: Intelegensia Media. 
Lunenburg, F. C. (2010). The Principal as Instructional Leader. National Forum of Educational and Supervision Journal, 27(4), 1-7.

Mahfuzhah, H., \& Anshari, A. (2018). Media Publikasi Humas Dalam Pendidikan. Al-Tanzim: Jurnal Manajemen Pendidikan Islam, 2(2), 137-149.

McEwan, E. K. (2003). Ten Traits of Highly Effective Principals: From Good to Great Performance. California: Corwin Press.

Mendels, P. (2012). The Effective Principal. Journal of Staff Development, 33(1), 54-58.

Miller, P. M. (2007). "Getting on the Balcony to See the Patterns on the Dance Floor Below": Considering Organizational Culture in a UniversitySchool-Community Collaboration. Journal of School Leadership, 17(2), 222245.

Mncube, V., \& Harber, C. (2010). Chronicling Educator Practices and Experiences in The Context of Democratic Schooling and Quality Education in South Africa. International Journal of Educational Development, 30(6), 614-624.

Mubasyaroh. (2017). Strategi Dakwah Persuasif dalam Mengubah Perilaku Masyarakat. Ilmu Dakwah: Academic Journal for Homiletic Studies, 11(2), 311-324.

Mulyadi, V. R. \& D. (2015). Kepemimpinan dan Perilaku Organisasi. Jakarta: Rajawali Press.

Myende, P. E. (2013). Sustaining School-Community Partnerships through Effective Communication. Communitas, 18, 76-94.

Naway, F. A. (2017). Komunikasi E Organisasi Pendidikan. Gorontalo: Ideas Publishing.

Pratiwi, Y. E., \& Sunarso, S. (2018). Peranan Musyawarah Mufakat (BUBALAH) dalam Membentuk Iklim Akademik Positif di Prodi PPKN FKIP UNILA. Sosiohumaniora, 20(3), 199-206.

Rahsel, Y. (2017). Kinerja Pegawai Universitas Padjadjaran Bandung: Iklim Kerja dan Motivasi. Manajemen Magister, 3(1), 107-123.

Siswanto, B. (2005). Manajemen Modern: Konsep dan Aplikasi. Bandung: Sinar Biru.

Siswatiningsih, I., Raharjo, K., \& Prasetya, A. (2019). Pengaruh Kepemimpinan Transformasional dan Transaksional terhadap Budaya Organisasi, Motivasi Kerja, Komitmen Oganisasional dan Kinerja Karyawan. Jurnal Bisnis dan Manajemen, 5(2), 146-157.

Swick, K. J. (2003). Communication concepts for strengthening family-schoolcommunity partnerships. Early Childhood Education Journal, 30(4), 275280.

Syam, A. R. (2017). Konsep Kepemimpinan Bermutu dalam Pendidikan Islam. Al-Ta'dib, 12(2), 49-69.

Taufiq, A. M. (2004). Praktik Manajemen Berbasis Al-Qur'an. Jakarta: Gema Insani. Tisnawati, E., \& Saefullah, K. (2005). Pengantar Manajemen. Jakarta: Kencana.

Tobin, J. (2014). Management and Leadership Issues for School Building Leaders. International Journal of Educational Leadership Preparation, 9(1), 114. 
Trianto. (2014). Pengantar Penelitian Pendidikan bagi Pengembangan Profesi Pendidikan dan Tenaga Kependidikan. Jakarta: Kencana.

Tyler, D. E. (2016). Communication Behaviors of Principals at High Performing Title I Elementary Schools in Virginia: School Leaders, Communication, and Transformative Efforts. Creighton Journal of Interdisciplinary Leadership, 2(2), 2-16.

Usman, Husaini. (2011). Manajemen Teori, Praktek dan Riset Pendidikan. Jakarta: PT Bumi Aksara.

Wentz, P. (1998). Successful Communications for School Leaders. NASSP Bulletin, 82(601), 112-115.

Widyastuti, T. (2017). Pengaruh Komunikasi Asertif terhadap Pengelolaan Konflik. Widya Cipta, I(1), 1-7.

Wisman, Y. (2017). Komunikasi Efektif dalam Dunia Pendidikan. Jurnal Nomosleca, 3(2), 646-654. 